Original Paper

\title{
Penerapan Computer Based Instruction Model Simulasi dalam Pembelajaran IPA Sekolah Dasar
}

\author{
Wiranda Bayu Aditama1*, Agus Ramdani2,3, Khairunnisa1 \\ 1 Pendidikan Guru Sekolah Dasar, Universitas Mataram, Mataram, Indonesia. \\ 2 Pendidikan Biologi, Universitas Mataram, Mataram, Indonesia. \\ ${ }^{3}$ Program Studi Magister Pendidikan IPA, Pascasarjana Universitas Mataram, Mataram, Indonesia.
}

\section{DOI: https://doi.org/10.29303/jcar.v3i1.651}

${ }^{*}$ Corresponding Author:

Wiranda Bayu Aditama,

Pendidikan Guru Sekolah

Dasar, Universitas Mataram,

Mataram, Indonesia.

Email:

bayuaditamalttk@gmail.com

\begin{abstract}
Abstrak: Penelitian ini bertujuan untuk meningkatkan hasil belajar kognitif siswa kelas III Sekolah Dasar pada pelajaran IPA. Penelitian ini termasuk dalam Penelitian Tindakan Kelas (Classroom Action Research). Tahapan penelitian ini terdiri dari dua siklus, yang dimana setiap siklus terdapat empat tahapan: (1) perencanaan; (2) pelaksanaan tindakan; (3) tahap observasi dan evaluasi, dan; (4) refleksi. Tindakan yang diberikan untuk meningkatkan hasil belajar kognitif siswa adalah dengan mengimplementasikan computer based instruction model simulasi. Hasil Penelitian Tindakan Kelas menunjukkan bahwa ketuntasan klasikal siklus I yaitu $75 \%$ mengalami peningkatan pada siklus II sebesar $83.3 \%$. Demikian pula dengan aktivitas belajar siswa terjadi peningkatan dari siklus I yaitu memperoleh skor 47.5 dengan kategori cukup aktif, pada siklus II menjadi 62.5 dengan kategori aktif. Sedangkan skor aktivitas guru juga mengalami peningkatan yaitu dari siklus I memperoleh skor 14.5 berkategori sangat baik, pada siklus II memperoleh skor 17.5 berkategori sangat baik. Dari hasil yang diperoleh dalam penelitian ini dapat disimpulkan bahwa penerapan computer based instruction model simulasi dapat meningkatkan hasil belajar IPA siswa kelas III SD tahun pelajaran 2014/2015.
\end{abstract}

Kata kunci: Hasil Belajar; Model Simulasi; Computer Based Intruction Model Simulasi.

\section{Pendahuluan}

Setiap negara bercita-cita untuk menjadi negara yang maju agar dapat bersaing di era globalisasi seperti saat ini. Ada banyak cara yang dapat dilakukan untuk memajukan negara, salah satunya melalui peningkatkan kualitas pendidikan negara tersebut. Kemajuan pada bidang pendidikan menjadi salah satu tolak ukur apakah negara tersebut negara maju atau negara berkembang. Sebagaimana pendapat yang disampaikan oleh Turkkahraman (2012) bahwa di negara maju, pengetahuan yang dihasilkan melalui penelitian dan pendidikan, tidak hanya digunakan untuk mewujudkan tujuan sosial dan ekonomi, tetapi juga digunakan untuk pengembangan pribadi individu di negara tersebut. Selain itu, pendidikan merupakan sarana untuk mencetak generasi penerus bangsa yang nantinya mampu bersaing di kancah dunia.

$$
\text { Turkkahraman (2012) juga }
$$
menyampaikan bahwa pendidikan merupakan prasyarat untuk pembangunan dan juga merupakan cara yang efektif untuk mengambil keputusan berdasarkan pengetahuan. Artinya bahwa dengan adanya pendidikan diharapkan 
dapat menciptakan dunia yang lebih aman, lebih sehat, dan lebih sejahtera sehingga dapat meningkatkan standar hidup dengan mengubah visi dan perspektif individu. Slamet et al (2014) berpendapat kemajuan pesat di bidang ilmu pengetahuan dan teknologi membutuhkan adanya SDM yang mampu bersaing, terampil dan profesional. Jika suatu negara menghasilkan output pendidikan yang tidak mampu bersaing, tidak terampil, dan tidak profesional kemungkinan untuk memajukan negara sulit untuk digapai.

Berdasarkan hal tersebut, jika melihat situasi dan kondisi pendidikan di Indonesia sekarang ini, yaitu masih banyak sekolah yang kekurangan sarana prasarana pendidikan, semakin meningkatnya anak putus sekolah di setiap jenjangnya salah satu contohnya di jenjang sekolah dasar dari 34 provinsi di Indonesia angka anak putus sekolah mencapai 39.213 anak (sumber: Buku Ikhtisar Data Pendidikan Tahun 2016/2017 halaman 17), kebijakan pergantian kurikulum yang terlalu cepat, menurunnya kualitas profesionalitas guru, dan kurangnya penguatan pendidikan karakter, beberapa hal inilah yang menyebabkan kemajuan dalam dunia pendidikan sulit dicapai.

Darmawan (2012) menyampaikan bahwa semakin majunnya zaman dan globalisasi seperti saat ini yang ditandai oleh meningkatnya produk dan penggunaan teknologi informasi, hal inilah yang menjadi dasar bergesernya konsepsi penyelenggaraan kegiatan belajar mengajar menjadi pembelajaran yang modern. Artinya bahwa, di era globalisasi saat ini banyak cara yang mungkin dapat dilakukan dalam rangka meningkatkan kualitas pendidikan, salah satunya melalui pemanfaatan teknologi informasi dalam proses pembelajaran baik itu sebagai alat bantu, sebagai multimedia, dan sebagainya. Pemanfaatan teknologi informasi ini menjadi solusi guru untuk berinovasi dalam pembelajarannya. Berinovasi dalam pembelajaran merupakan kewajiban seorang guru, karena dengan hal tersebut diharapkan dapat meningkatkan hasil belajar siswa menjadi lebih baik, dan proses pembelajaranpun akan menjadi lebih efektif dan efisien. Hal ini sejalan dengan pendapat Pandolfini (2013) yang mengungkapkan seorang guru sebisa mungkin dapat menciptakan lingkungan yang lebih inovatif untuk pengajaran dan pembelajaran yang efektif.

Selain itu, agar proses belajar mengajar berjalan efektif maka diperlukan suatu model pembelajaran yang sesuai dengan karakter siswa, mata pelajaran yang disampaikan, suasana, dan prasarana penunjang. Kazu et al (2005) menyampaikan bahwa dalam sistem pembelajaran yang ada, setiap individu dalam kelompok sangat bergantung pada metode program dan pengajaran yang dipilih. Artinya bahwa guru disarankan untuk mengenali dan mengetahui karakteristik belajar siswanya, dengan hal tersebut kemungkinan besar guru dapat menemukan dan menentukan metode ataupun model pembelajaran yang sesuai dengan karakteristik siswanya baik dalam hal gaya belajar, minat, dan perkembangan pengetahuan siswanya.

Guru sebagai salah satu fasilitator dalam dunia pendidikan khususnya di sekolah sering kali belum dapat bekerja sebagaimana mestinya. Hal itu ditandai dengan kegiatan pembelajaran di kelas belum bisa dikelola dengan baik. Guru mempunyai peran yang dominan dan terlalu aktif sehingga menyababkan siswa menjadi pasif dan diam. Abdi (2014) menyampaikan bahwa kelas tradisional sering terlihat seperti pertunjukan satu orang dengan pelajar yang belum pernah terlibat. Kelas tradisional biasanya didominasi oleh instruksi langsung dan sepihak. Pembelajaran dengan pendekatan tradisional beranggapan bahwa ada pengetahuan yang pasti bahwa siswa harus mengetahui. Hal yang sama diungkapkan oleh Ahmed (2013) bahwa selama bertahun-tahun, gaya pengajaran tradisional atau secara khusus, pengajaran berpusat pada guru telah dominan dalam pendidikan tinggi di Amerika Utara. Di 
kelas tradisional, siswa menjadi pelajar pasif, atau lebih tepatnya hanya penerima pengetahuan dan kebijaksanaan guru. Mereka tidak memiliki kendali atas pembelajaran mereka sendiri. Artinya bahwa setiap guru harus mampu menempatkan diri dalam setiap pembelajaran agar tidak selalu menjadi pusat belajar siswa salah satunya dengan cara membuat pembelajaran yang mengaktifkan dan meningkatkan kemandirian siswa misalnya melalui sebuah model, pendekatan, metode, atau media pembelajaran. Masalah lain yang juga cenderung sering terlihat bahwa gaya penyampaian materi oleh guru terlalu monoton artinya guru hanya mengandalkan kemampuan sendiri tanpa menggunakan alat atau media pembelajaran, sehingga hal ini menyebabkan motivasi siswa dalam belajar mungkin menjadi berkurang dan pada akhrinya akan berdampak juga pada penurunan hasil belajar siswanya.

Berdasarkan hal tersebut, media pembelajaran dapat dijadikan guru sebagai salah satu solusi yang dapat meningkatkan hasil belajar siswa di kelas. Pentingnya media pembelajaran dalam proses belajar mengajar juga disampaikan oleh Tabor dan Minch (2013) yang menyatakan bahwa pemanfaatan media pembelajaran dapat mempertinggi proses pembelajaran siswa yang pada akhirnya dapat meningkatkan hasil belajar yang akan dicapainya. Selain itu, Kozma (1994) berpendapat belajar dengan media adalah proses pelengkap dimana seorang pelajar dan media berinteraksi untuk memperluas atau menyempurnakan model pembelajaran. Berdasarkan beberapa pendapat di atas, bisa dikatakan bahwa posisi media pembelajaran dalam kegiatan belajar mengajar cukup penting, karena media pembelajaran dapat membuat pembelajaran menjadi lebih menarik dan meningkatkan motivasi siswa dalam belajar, dan pada akhirnya dapat meningkatkan hasil belajar siswa. Dalam hal ini, media pendidikan dapat berupa model/alat peraga, flowchart, tabel-tabel, dan media berbasis komputer.
Pemanfaatan teknologi di era globaliasi juga ditandai oleh meningkatnya penggunaan perangkat komputer di hampir seluruh segi kehidupan, khususnya di bidang pendidikan. Di antara pemanfaatannya adalah untuk kepentingan pembelajaran, yaitu membantu para guru dalam meningkatkan mutu pembelajaran, terkait dengan peningkatan mutu pembelajaran salah satunya komputer dimanfaatkan dalam bentuk pembelajaran berbasis komputer (Computer Based InstructionCBI). Sebagaimana halnya seperti yang disampaikan oleh Winter et al (2008) bahwa lingkungan belajar berbasis komputer memberikan peluang penting untuk membina pembelajaran. Fungsi dari pembelajaran berbasis komputer itu sendiri di antaranya memberikan kemudahan bagi guru dalam kegiatan belajar mengajarnya di kelas, misalanya sebagai multimedia, sebagai media presentasi dan juga demonstrasi. Selain itu, pembelajaran berbasis komputer memberikan kesempatan kepada siswa untuk belajar mandiri tanpa harus selalu bergantung kepada guru atau dalam hal ini pembelajaran tersebut memfasilitasi pembelajaran kepada pengguna yang menggunakannya. Hal ini sejalan dengan yang disampaikan Winter et al (2008) bahwa lingkungan belajar berbasis komputer membuat individu dapat merencanakan, memantau, dan mengendalikan pembelajaran mereka secara efektif. Rusman (2012) juga berpendapat bahwa pada pembelajaran berbasis komputer, siswa secara langusng melakukan interaksi dengan multimedia interaktif yang sudah tersedia di dalam perangkat komputer, sehingga dalam hal ini guru bertugas sebagai pengembang dan perancang pembelajaran.

Berdasarkan hal tersebut penelitian ini bertujuan untuk mengimplementasikan computer based instruction model simulasi dalam pembelajaran IPA di SD guna meningkatkan hasil belajar siswa.

Hasil belajar merupakan pencapaian siswa setelah melalui suatu proses pembelajaran. Hal ini sejalan dengan apa yang 
disampaikan Maher (2004) bahwa hasil belajar merupakan pencapaian aktual siswa berupa ukuran nilai pendidikan yang lebih realistis dan nyata. Sementara Potter \& Kustra (2012) menyampaikan bahwa hasil belajar merupakan pernyataan yang menunjukkan apa yang akan diketahui siswa, nilai yang akan diperoleh setelah melakukan kegiatan pembelajaran. Artinya bahwa hasil belajar merupakan tujuan akhir atau tujuan pembelajaran yang akan dicapai siswa setelah melalui kegiatan pembelajaran. Wang \& Chen (2015) sependapat terkait dengan pernyataan tersebut bahwa hasil belajar merupakan tujuan akhir pendidikan dan menjadi indikator langsung untuk mengevaluasi kurikulum yang berlaku.

Potter \& Kustra (2012) menyampaikan ada tiga ranah yang dapat diukur terkait dengan hasil belajar yaitu kognitif, sikap, dan keterampilan. Pada penelitian ini, hasil belajar yang diukur adalah hasil belajar kognitif siswa pada pelajaran IPA, dimana dalam hal ini hasil belajar kognitif lebih mengarah pada kemampuan dan kecakapan intelektual berpikir seorang siswa. Potter \& Kustra (2012) berpendapat ada beberapa alasan terkait pentingnya mengukur hasil belajar, di antaranya: (1) hasil belajar dapat digunakan untuk memberikan panduan bagi siswa, sehingga siswa tahu apa yang diharapkan dari dirinya, dan dengan demikian siswa juga tahu apa yang harus difokuskan dalam belajar; (2) hasil belajar meningkatkan motivasi, karena hasil belajar menjadi alasan atas hal yang telah dilalui melalui proses pembelajaran; (3) hasil belajar membuat kinerja siswa menjadi lebih baik pada tugas dan pengujian, karena dengan hasil belajar siswa tahu persis apa yang diharapkan siswa tunjukkan, dan siswa lebih mampu menunjukkan hal-hal tersebut; dan (4) mengukur hasil belajar membantu guru guru fokus pada ouput, bukan input.

Computer Based Instruction merupakan kegiatan belajar mengajar dengan memanfaatkan perangkat komputer dalam proses belajar mengajar. Hal yang sama disampaikan oleh Akcay et al. (2006) bahwa computer based instruction merupakan sebuah metode, yang menggunakan komputer dalam media pembelajaran, yang dapat memperkuat motivasi dan proses belajar siswa. Computer based instruction ini juga memberikan kesempatan kepada siswa untuk belajar sesuai dengan kecepatan mereka masing-masing, selain itu computer based instruction membuat pembelajaran menjadi lebih aktif. Mayer \& Moreno (2002) menambahkan computer based instruction merupakan pembelajaran yang terdiri dari gambar seperti animasi dan katakata seperti narasi yang dimana hal tersebut berpotensi untuk meningkatkan pemahaman siswa terkait dengan hal yang dipelajarinya. Selain itu, computer based instruction juga diartikan sebagai pembelajaran yang menggunakan perangkat komputer dimana di dalamnya berisi muatan pembelajaran yang menyampaikan informasi kepada penggunanya melalui interaksi dengan program komputer baik dalam bentuk CD, DVD, flashdisk, dan lain-lain (Heinich et al., 1985; Darmawan, 2012; Rusman, 2013). Intinya bahwa computer based instruction merupakan pembelajaran yang memanfaatkan perangkat komputer dalam kegiatan belajar mengajar yang berisi muatan pembelajaran dan memfasilitasi belajar kepada individu yang menggunakannya baik dalam bentuk CD, DVD, flashdisk, dan lainnya yang di dalamnya menggabungkan elemen media baik audio, video, gambar, grafis, maupun animasi.

Setiap pembelajaran memiliki karakteristiknya masing-masing, begitu juga dengan computer based instruction. Susilana dan Riyana (2009) berpendapat karakteristik dari pembelajaran ini diantaranya yaitu: (1) representasi isi; (2) visualisasi multimedia; (3) full colour; (4) tipe pembelajaran yang bervariasi; (5) respon pembelajaran dan penguatan; (6) self evaluation, dan; (7) dapat digunakan secara klasikal atau individual. Karakteristik yang disampaikan tersebut dijadikan dasar atau landasan dalam mengembangkan dan mengimplementasikan 
computer based instruction dala kegiatan belajar mengajar.

Computer based instruction terdiri dari beberapa model yang di mana setiap model memiliki karakteristiknya masing-masing. Rusman (2012) berpendapat model computer based instruction ini terdiri dari: (1) model drill and practice; (2) model tutorial, (3) model simulasi, (4) model instructional games. Molenda menambahkan satu model dalam computer based instruction yaitu model hypermedia, model hypermedia ini memungkinkan pengguna mengakses teks dan grafis dalam urutuan yang paling sesuai dengan perkembangan pengetahuan penggunanya, (Sugar \& Brown, 2008). Dari beberapa model tersebut, model pengembangan yang digunakan adalah model simulasi. Model simulasi merupakan model computer based instruction yang menyajikan materi berupa simulasi-simulasi dalam bentuk animasi yang menarik. Sejalan dengan yang disampaikan Rusman (2012) bahwa model simulasi merupakan model pengembangan computer based instruction yang menyampaikan materi pelajaran melalui simulasi-simulasi pembelajaran berupa animasi yang menerangkan konten dengan menarik, nyata, dan menyatukan unsur atau komponen media menjadi satu kesatuan yang harmonis. Computer based instruction model simulasi memberikan beberapa bentuk panduan kepada siswa, di antaranya panduan berupa petunjuk pada poin kritis dan umpan balik tentang kinerja siswa, selain itu juga model simulasi dapat memandu dan memastikan siswa memperhatikan apa yang penting (Sumber: Center on Technology and Disability dalam Buku Learning with Computer Games and Simulations).

Menerapkan computer based instruction dalam proses belajar mengajar memiliki beberapa kelebihan, Lai (2006) berpendapat bahwa dengan pembelajaran berbasis komputer guru dapat memberikan pembelajaran yang menyenangkan dan aktivitas belajar yang komunikatif, mengurangi tekanan belajar dan kecemasan, memberikan pelajaran berulang sesering yang diperlukan, mendorong motivasi belajar, mempengaruhi sikap belajar, dan membangun strategi dan kepercayaan diri siswa. Computer based instruction juga tidak terlepas dari kekurangannya, Heinich et al (2002) menyampaikan bahwa computer based instruction sangat mudah untuk diduplikasi tanpa izin dari pengembangnya, kemudian juga dalam computer based instruction memberikan harapan yang tinggi bagi penggunanya bahwa belajar terjadi dengan sedikit dan tanpa adanya usaha, komputer juga hanya digunakan untuk mengajarkan pada tujuan yang terbatas, mematikan kreativitas siswa, interaksi sosial berkurang, penggunaan komputer secara terus menerus memudarkan motivasi belajar siswa. Kelebihan dan kelemahan ini, dijadikan dasar dalam penerapan computer based instruction dan berusaha untuk meminimalisir kelemahan-kelemahannya sehingga dapat meningkatkan hasil belajar siswa.

Berdasarkan tinjauan literatur di atas, penelitian ini bertujuan untuk meningkatkan hasil belajar kognitif siswa SD pada pelajaran IPA melalui implementasi computer based instruction model simulasi.

\section{Metode}

Jenis penelitian ini adalah Penelitian Tindakan Kelas (Classroom Action Research). Penelitian ini merupakan penelitian tindakan (action research) oleh seorang guru yang sekaligus sebagai peneliti di kelasnya atau bersama-sama dengan orang lain (kolaborasi) dengan jalan yang diawali dengan kegiatan perencanaan, pelaksanaan, sampai dengan kegiatan merefleksikan tindakan secara bersama-sama yang dimana tujuan dari penelitian ini sendiri adalah untuk memperbaiki atau meningkatkan mutu (kualitas) kegiatan belajar mengajar di kelasnya melalui suatu tindakan (treatment) 
tertentu dalam suatu siklus (Kunandar 2010: 45).

Berdasarkan hal tersebut, maka dilakukan suatu tindakan dengan mengimplementasikan Computer Based Instruction Model Simulasi pada pelajaran IPA materi pokok Gerak Benda, dengan harapan dapat memecahkan masalah rendahnya hasil belajar IPA siswa, sehingga setelah mengikuti kegiatan pembelajaran, diharapkan hasil belajar IPA siswa kemungkinan bisa meningkat. Penelitian tindakan kelas ini, akan dihentikan jika sudah mencapai indikator keberhasilan yang telah ditetapkan. Adapun rancangan penelitiannya sebagai berikut.

Setiap siklus ada 2 kali pertemuan dengan alokasi waktu yang sama yaitu $4 \times 35$ menit dalam satu siklus. Adapun langkahlangkah dalam penelitian tindakan kelas ini terdiri dari perencanaan, pelaksanaan, pengamatan, dan refleksi seperti yang tergambar pada gambar berikut.

\section{Siklus I}

1) Tahap Perencanaan

Tahap perencanaan merupakan persiapan yang dilakukan sehubungan dengan pelaksanaan PTK.

2) Tahap Pelaksanaan Tindakan

Pada tahap ini guru melakukan pembelajaran di kelas dengan menerapkan Computer Based Instruction Model Simulasi pada Mata Pelajaran IPA Materi Pokok Gerak Benda sesuai dengan rencana program yang telah disusun.

3) Tahap Observasi dan Evaluasi

Pada tahap ini dilakukan pengamatan terhadap pelaksanaan tindakan dengan menggunakan lembar instrumen observasi yang telah dibuat, dalam hal ini guru dan siswa diamati oleh observer mengenai pelaksanaan kegiatan pembelajaran. Observasi ini dilakukan sebagai acuan perbaikan untuk siklus berikutnya. Kegiatan evaluasi juga dilakukan bersamaan dengan tahap pelaksanaan tindakan. Evaluasi yang diadakan dalam penelitian ini, berupa tes pilihan ganda sebanyak 20 soal.
4) Refleksi

Pada tahap ini, peneliti dan observer mengkaji pelaksanaan dan hasil yang diperoleh dari pemberian. Hasil refleksi yang diperoleh ini, digunakan sebagai acuan untuk memperbaiki serta menyempurnakan perencanaan dan pelaksanaan tindakan pada siklus selanjutnya.

\section{Siklus II}

Hasil akhir dari refleksi dan evaluasi pada siklus I digunakan sebagai dasar untuk melakukan perencanaan pada siklus II dan seterusnya. Hal-hal yang kurang dalam pelaksanaan siklus I akan diperbaiki pada siklus II sedangkan yang sudah baik dipertahankan.

Subyek penelitian ini difokuskan pada siswa kelas III tahun pelajaran 2014/2015 SDN Cakrasia dengan jumlah 24 orang siswa, yang terdiri dari 15 orang siswa laki-laki dan 9 orang siswa perempuan. Instrumen yang digunakan untuk mengumpulkan data penelitian adalah:

1. Tes Hasil Belajar

Untuk mengetahui hasil belajar IPA siswa, dengan menerapakan Computer Based Instruction Model Simulasi maka digunakan instrumen penilaian berupa tes objektif terdiri dari 20 soal untuk setiap siklus.

2. Lembar Pengamatan (Observasi)

Lembar pengamatan yang digunakan dalam penelitian ini adalah lembar observasi terstruktur. Lembar observasi terstruktur yakni lembar pengamatan yang di dalamnya terdapat petunjuk terinci tentang prosedur yang dilakukan sehingga observer hanya melakukan checklist.

3. Lembar Observasi Aktivitas Guru

Lembar observasi aktivitas guru yang dimaksud dalam penelitian ini adalah lembar yang digunakan untuk mengamati aktivitas guru dalam menerapakan Computer Based Instruction Model Simulasi.

4. Lembar Observasi Aktivitas Siswa

Lembar observasi aktivitas siswa yang dimaksud adalah lembar yang digunakan untuk mengamati aktivitas siswa terhadap 
langkah-langkah yang harus dilakukan dalam Computer Based Instruction Model Simulasi.

Prosedur pengumpulan data diartikan sebagai proses atau kegiatan yang dilakukan peneliti untuk mengungkap atau menjaring fenomena, informasi atau kondisi lokasi penelitian sesuai dengan lingkup penelitian. Prosedur pengumpulan data yang digunakan dalam penelitian ini adalah:

1. Data tentang hasil belajar IPA diperoleh melalui hasil tes evaluasi setiap akhir siklus. Analisis data yang digunakan terkait dengan data hasil belajar adalah analisis kuantitatif dengan menggunakan rumus sebagai berikut.

(1) Nilai hasil belajar IPA siswa, dengan rumus: Nilai Siswa $=\frac{\text { jumlah benar }}{\text { jumlah maksimal }} \times 100$

(2) Ketuntasan belajar klasikal, dengan rumus: Ketuntasan Klasikal $=\frac{\text { jumlah siswa yang tuntas }}{\text { jumlah seluruh siswa }}$ x100

Berdasarkan hal tersebut, hasil belajar IPA dikatakan tuntas apabila mencapai nilai Kriteria Ketuntasan Minimal (KKM) $\geq 75$ dengan ketuntasan klasikal sebesar $80 \%$.

2. Data tentang aktivitas belajar siswa dan aktivitas mengajar guru diambil oleh observer dengan lembar observasi yang dilakukan pada setiap pertemuan. Data hasil observasi ini menggunakan analisis data kualitatif, dengan rumus:

Nilai Aktivitas $=\frac{\text { jumlah skor yang diperoleh }}{\text { Skor maksimum }} \times 100$

Berdasarkan hal tersebut, aktivitas belajar siswa dikatkan berhasil apabila berkategori aktif, dengan berpedoman pada tabel berikut.

\section{Tabel 1. Kriteria Aktivitas Siswa}

\begin{tabular}{lll}
\hline Interval & Skor & Kategori \\
\hline $\mathrm{Mi}+1,5 \mathrm{SDi} \leq \mathrm{M} \leq$ & $67,5 \leq \mathrm{M} \leq 72$ & Sangat Aktif \\
$\mathrm{SMi}$ & & \\
$\mathrm{Mi}+0,5 \mathrm{SDi} \leq \mathrm{M}<$ & $52,5 \leq \mathrm{M}<$ & Aktif \\
$\mathrm{Mi}+1,5 \mathrm{SDi}$ & 67,5 & \\
$\mathrm{Mi}-0,5 \mathrm{SDi} \leq \mathrm{M}<$ & $37,5 \leq \mathrm{M}<$ & Cukup Aktif \\
$\mathrm{Mi}+0,5 \mathrm{SDi}$ & 52,5 & \\
$\mathrm{Mi}-1,5 \mathrm{SDi} \leq \mathrm{M}<$ & $22,5 \leq \mathrm{M}<$ & Kurang Aktif \\
$\mathrm{Mi}-0,5 \mathrm{SDi}$ & 37,5 & Tidak Aktif \\
$0 \leq \mathrm{M}<\mathrm{Mi}-1,5 \mathrm{SDi}$ & $0 \leq \mathrm{M}<22,5$ & \\
\hline
\end{tabular}

Sedangkan indikator keberhasilan aktivitas guru dikatakan berhasil apabila berkategori baik, berdasarkan pedoman pada tabel berikut.

\section{Tabel 2. Kriteria Aktivitas Guru}

\begin{tabular}{lll}
\hline Interval & Skor & Kategori \\
\hline $\mathrm{Mi}+1,5 \mathrm{SDi} \leq \mathrm{M} \leq$ & $13,5 \leq \mathrm{M} \leq$ & Sangat Baik \\
$\mathrm{SMi}$ & 18 & \\
$\mathrm{Mi}+0,5 \mathrm{SDi} \leq \mathrm{M}<\mathrm{Mi}$ & $10,5 \leq \mathrm{M}<$ & Baik \\
$+1,5 \mathrm{SDi}$ & 13,5 & \\
$\mathrm{Mi}-0,5 \mathrm{SDi} \leq \mathrm{M}<\mathrm{Mi}$ & $7,5 \leq \mathrm{M}<$ & Cukup Baik \\
$+0,5 \mathrm{SDi}$ & 10,5 & \\
$\mathrm{Mi}-1,5 \mathrm{SDi} \leq \mathrm{M}<\mathrm{Mi}$ & $4,5 \leq \mathrm{M}<$ & Kurang Baik \\
$-0,5 \mathrm{SDi}$ & 7,5 & Tidak Baik \\
$0 \leq \mathrm{M}<\mathrm{Mi}-1,5 \mathrm{SDi}$ & $0 \leq \mathrm{M}<4,5$ & \\
\hline
\end{tabular}

Dokumentasi bertujuan untuk membuktikan bahwa penelitian ini benarbenar dilaksanakan. Dokumentasi yang digunakan berupa: daftar hadir, RPP, evaluasi, dan hasil foto..

\section{Hasil dan Pembahasan}

Pada penelitian ini, evaluasi dilakukan untuk memperoleh data hasil belajar siswa yang dilaksanakan setiap akhir siklus, sedangkan observasi dilakukan untuk memperoleh data terkait aktivitas guru dan dan juga siswa dalam pembelajaran di kelas diperoleh dari lembar observasi. Adapun hasil penelitian setiap siklus sebagai berikut.

Kegiatan Siklus I dilakukan sebanyak 2 kali pertemuan. Pertemuan pertama dilakukan pada tanggal 17 Maret 2015 selama $2 \times 35$ menit dengan membahas materi Gerak Benda dan Macam-macam Gerak pada Benda, pertemuan kedua dilaksanakan pada tanggal 19 Maret 2015 dilaksanakan selama 2 × 35 menit, dengan melanjutkan materi yang belum terselesaikan pada pertemuan pertama selama $1 \times 35$ menit dan evaluasi Siklus I selama $1 \times 35$ menit. Soal evaluasi diberikan dalam bentuk tertulis sebanyak 20 soal pilihan ganda. Adapun langkah-langkah pelaksanaan penelitian pada Siklus I adalah sebagai berikut. 
Tahap perencanaan dalam Penelitian Tindakan Kelas ini dilakukan beberapa kegiatan sebagai berikut: (1) Tersiapkan materi pembelajaran yang akan dibahas; (2) Tersiapkan RPP dengan penerapan Computer based instruction Model Simulasi; (3) Tersiapkan lembar observasi aktivitas guru dan aktvitas siswa; (4) Tersiapkan media Komputer/Laptop dan CD Pembelajaran tentang Gerak Benda; (5) Tersiapkan soal evaluasi; (6) Tersiapkan pedoman penskoran soal evaluasi.

$$
\text { Selanjutnya dilakukan tahap }
$$
pelaksanaan tindakan yaitu melaksanakan kegiatan belajar mengajar di kelas yang dituangkan dalam skenario pembelajaran. Kegiatan yang dilaksanakan adalah menerapkan Computer based instruction Model Simulasi pada pembelajaran IPA kelas III SDN 21 Cakrasia untuk melihat tingkat aktivitas guru dan juga siswa dalam kegiatan belajar mengajar. Tahap pelaksanaan tindakan yang dilakukan sebagai berikut.

Guru mengawali kegiatan dengan mengucapkan salam pembuka, siswa menjawab salam dengan penuh semangat dan diikuti dengan aktivitas berdoa yang dipimpin oleh ketua kelas. Selanjutnya guru memberikan motivasi kepada seluruh siswa agar belajar dengan baik dan serius sehingga dapat menambah ilmu dan wawasan mereka. Setelah siswa mulai termotivasi, seharusnya guru memberikan apersepsi melalui sebuah pertanyaan yang mengaitkan alam sekitar dengan materi pembelajaran namun dalam hal ini guru tidak memberikan apersepsi sebagaimana yang tertera dalam skenario pembelajaran adapun hal ini terjadi karena guru lupa, kemudian guru menyampaikan tujuan pembelajaran dan siswa mendengarkan tujuan pembelajaran yang disampaikan oleh guru namun masih ada beberapa siswa yang tidak mendengarkan dan memperhatikan guru karena siswa sibuk dengan aktivitasnya sendiri. Selanjutnya guru menjelaskan kepada siswa kegiatan pembelajaran pada hari ini yaitu Computer based instruction Model
Simulasi serta mempersiapkan sumber, media, dan alat kelengkapan belajar yang menunjang Computer based instruction, mendengarkan hal tersebut siswa begitu antusias mengikuti kegiatan pembelajaran.

Guru memfasilitasi masing-masing satu Laptop untuk masing-masing meja. Guru menuntun siswa untuk membuka $C D$ Pembelajaran dengan mencontohkan pada slide yang ditampilkan melalui LCD Proyektor, siswa mengikuti arahan dari guru/moderator dan memperhatikan LCD, dalam hal ini ada beberapa siswa yang sudah bisa mengoperasikan Laptop, namun mereka sibuk memainkan Laptop tanpa mendengarkan arahan guru. Setelah semua siswa membuka CD Pembelajaran, guru menerapkan Computer based instruction Model Simulasi yang dimulai dengan menampilkan judul program Computer based instruction yang berjudul "Gerak Benda" melalui LCD Proyektor dan siswa memperhatikan dari Laptop yang sudah disedikan serta siswa terlihat sangat tertarik dan terkagum-kagum dengan CD Pembelajaran. Setelah itu, guru mengajak siswa untuk membuka menu petunjuk dan guru menjelaskan petunjuk penggunaan $C D$ Pembelajaran mulai dari tombol-tombol dan simbol-simbol yang ada dalam CD Pembelajaran melalui LCD Proyektor, saat guru menerangkan petunjuk penggunaan $C D$ Pembelajaran masih ada beberapa pasangan siswa yang tidak memperhatikan sehingga beberapa pasangan siswa tersebut sulit mengoperasikan CD Pembelajaran melalui Laptop. Langkah selanjutnya, guru menuntun siswa melalui LCD Proyektor untuk membuka menu materi pembelajaran, guru membimbing beberapa pasangan siswa yang masih mengalami kesulitan mengoperasikan CD Pembelajaran dalam membuka menu materi pembelajaran, sebelum menyajikan materi guru menerangkan kepada siswa bahwa di dalam CD Pembelajaran terdapat tiga karakter yang akan membahas masing-masing materi yang berbeda. 
Setelah itu, guru mengajak siswa untuk menekan atau membuka karakter pertama tentang Gerak Benda, siswa menekan karakter pertama yang diarahkan oleh guru. Kemudian guru memberikan waktu untuk siswa agar dapat memahami materi yang ada dalam karakter pertama, dan siswa mencoba memahami materi yang ada dalam karakter pertama, ketika guru meminta siswa untuk memahami materi dalam karakter pertama masih banyak siswa yang tidak fokus dan tidak membaca materi tersebut, sehingga hal ini akan menyebabkan siswa tidak memahami setiap materi. Saat siswa memperhatikan materi, ada beberapa siswa yang mengajukan pertanyaan yang berkaitan dengan materi dalam karakter pertama, dan guru menjawab pertanyaan yang diajukan siswa. Setelah karakter pertama dirasa sudah dipahami oleh siswa, guru mengajak siswa untuk kembali ke menu materi dengan menekan tombol kembali, dan ketika hal ini dilakukan masih ada beberapa pasang siswa yang salah dalam menekan, kondisi ini terjadi karena siswa baru pertama kali melakukan Computer based instruction Model Simulasi.

Setelah kembali ke menu materi pembelajaran, guru mengajak siswa untuk menekan karakter kedua yang berisi materi tentang Macam-macam Gerak pada Benda, siswa menekan apa yang diarahkan guru. Adapun dalam karakter kedua ini, terdapat enam simulasi dari enam simulasi tersebut ada tiga simulasi yang disampaikan guru dan sisanya dilanjutkan pada pertemuan kedua. Kemudian guru mengajak siswa untuk menekan simulasi pertama, ketika membuka simulasi pertama dibuka siswa begitu terlihat tertarik terhadap simulasi yang ada dalam CD Pembelajaran tersebut, namun dalam hal ini ada beberapa pasang siswa yang tidak mengikuti perintah guru. Setelah semua siswa membuka simulasi pertama, guru memberikan waktu kepada siswa untuk memperhatikan simulasi gerak pada benda yang terjadi dan memahami penjelasannya, kegiatan ini dilakukan berulang untuk setiap simulasinya.
Langkah selanjutnya, setelah membuka dan memahami materi dalam karakter pertama dan kedua siswa diberikan kesempatan untuk bertanya kepada guru apabila ada materi atau simulasi yang belum dipahami, namun tidak ada siswa yang bertanya karena saat mereka diminta untuk memahami materi atau simulasi ada beberapa pasangan siswa yang sibuk dengan aktivitasnya sendiri. Selanjutnya guru memberikan penguatan, dan melakukan tanya jawab dengan siswa terhadap materi yang sudah disampaikan, saat melakukan tanya jawab hanya beberapa siswa yang berani mengangkat tangan dan menjawab pertanyaan guru.

Pada pertemuan kedua, guru mereview pertemuan pertama dan melanjutkan materi yang belum terselesaikan melalui penerapan Computer based instruction Model Simulasi. Mengacu pada penyelesaian jawaban siswa, guru membantu siswa membuat penegasan dan kesimpulan tentang materi pembelajaran yang telah dibahas.

Tahap selanjutnya adalah observasi. Selama pelaksanaan tindakan diadakan observasi untuk mengetahui kesesuaian rencana pembelajaran atau skenario pembelajaran dengan pelaksanaan pembelajaran. Pelaksanaan obeservasi aktivitas guru dan siswa selama proses pembelajaran berlangusng dinilai oleh dua orang observer. Kegiatan pada tahap ini, dilakukan observasi terhadap kegiatan mengajar guru di dalam kelas oleh Ibu A guru kelas III SDN Cakrasia menggunakan lembar observasi guru yang telah disediakan dan telah disosialisasikan cara penggunaannya sebelumnya. Hasil observasi aktivitas mengajar pada Siklus I diperoleh skor rata-rata 14,5 dengan kategori sangat baik. Hal ini menunjukkan indikator ketercapaian penelitian tentang aktivitas guru sudah tercapai. Selain itu, dilakukan observasi terhadap kegiatan belajar siswa di dalam kelas yang dilakukan oleh observer yaitu NW mahasiswi PGSD selaku rekan peneliti, observer menggunakan lembar observasi 
siswa yang telah disediakan dan disosialisasikan cara penggunaannya sebelumnya. Hasil observasi aktivitas siswa pada Siklus I adalah 47,5 dengan kriteria cukup aktif. Hasil tersebut belum mencapai standar indikator keberhasilan yang telah ditentukan sebagai target ketuntasan yaitu jika aktivitas belajar siswa telah mencapai kategori aktif. Oleh karena itu, peneliti harus lebih meningkatkan aktivitas belajar siswa pada siklus berikutnya.

Tahap selanjutnya adalah evaluasi. Adapun untuk mengetahui ketercapaian siswa pada pembelajaran tentang "Gerak Benda dan Macam-macam Gerak pada Benda" dengan menerapkan Computer based instruction Model Simulasi, maka pada pertemuan kedua dilakukan evaluasi. Kegiatan evaluasi ini diberikan secara individu dengan memberikan soal pilihan ganda yang berjumlah 20 soal kepada siswa secara tertulis. Evaluasi Siklus I dilakukan pada tanggal 19 Maret 2015. Berdasarkan data hasil belajar, terlihat bahwa dari 24 siswa ada 18 orang siswa yang tuntas sedangkan siswa yang belum tuntas ada 6 orang siswa, adapun nilai tertinggi 100 dan nilai terendah 60 . Persentase ketuntasan hasil belajar siswa yaitu $75 \%$. Hasil yang diperoleh pada Siklus I masih belum berhasil, hal ini berdasarkan pada nilai persentase ketuntasan yang mendapat $75 \%$ dari 24 orang siswa. Maka dari itu perlu dilakukan perbaikan pada siklus selanjutnya.

Tahapan selanjutnya yang dilakukan adalah merefleksikan pembelajaran. Berdasarkan hasil penelitian Siklus I, baik hasil observasi proses belajar mengajar maupun hasil evaluasi "Gerak Benda dan Macammacam Gerak pada Benda dalam hal ini aktivitas siswa selama proses pembelajaran berlangsung masih sangat kurang. Oleh karena itu, refleksi dilakukan untuk menentukan kekurang-kekurangan yang terjadi dan selanjutnya diadakan perbaikanperbaikan maupun penyempurnaan dalam siklus selanjutnya. Adapun hasil refleksi pada Siklus I adalah sebagai berikut.
Kekurangan dalam aktivitas guru: (1) Pada pertemuan pertama, guru tidak melakukan apersepsi berupa pertanyaan yang mengaitkan materi dengan kehidupan nyata sehingga konsep dasar siswa terhadap materi tidak terbangun dengan baik; (2) Pada saat penyampaian materi, guru belum menciptakan kondisi atau suasana belajar yang kondusif, sehingga masih banyak siswa yang ribut dan sibuk dengan aktivitasnya sendiri; (3) Guru kurang mampu mengelola siswa, sehingga ada beberapa pasangan siswa yang tidak mengikuti perintah guru dalam mengoperasikan CD Pembelajaran dan Laptop; (4) Guru masih kurang dalam membimbing beberapa pasangan siswa yang masih kesulitan dalam mengoperasikan CD Pembelajaran.

Kekurangan dalam aktivitas siswa: (1) Saat guru mengajukan pertanyaan, siswa tidak mengangkat tangan dan lebih suka menjawab bersama-sama karena siswa belum percaya diri menjawab pertanyaan yang diajukan guru secara individu; (2) Siswa mengalami kesulitan dalam penerapan Computer based instruction Model Simulasi, karena pertama kali digunakan di sekolah tersebut; (3) Masih ada beberapa pasangan siswa yang mengalami kesulitan dalam mengoperasikan CD Pembelajaran; (4) Siswa kurang percaya diri dalam menyampaikan pendapat dan masih saling menangguhkan diri dengan teman yang lain, serta kesulitan dalam memberikan tanggapan saat diajukan pertanyaan oleh guru; (5) Ada beberapa pasangan siswa yang sudah bisa mengoperasikan CD Pembelajaran, namun tidak mengikuti petunjuk dari moderator atau guru sehingga belajarnya menjadi tidak terstruktur; (6) Masih banyak siswa yang belum memahami petunjuk CD Pembelajaran, hal ini menyebabkan banyak siswa yang salah dalam menekan tombol sehingga tidak sesuai dengan yang diperintahkan guru; (7) Masih banyak siswa yang kurang memperhatikan dan memahami setiap simulasi yang ada dalam CD Pembelajaran, sehingga saat diberikan umpan 
balik oleh guru siswa tidak mampu menanggapi pertanyaan guru; (8) Masih banyak siswa yang belum bisa menyimpulkan pembelajaran.

Kekurangan dalam evaluasi belajar siswa. Setelah dilakukan evaluasi pada pertemuan kedua, masih terdapat siswa yang belum mengerti tentang materi yang ada dalam CD Pembelajaran, hal ini disebabkan karena masih banyak siswa yang kurang memperhatikan dan tidak berusaha memahami simulasi yang ada dalam CD Pembelajaran, siswa hanya sibuk dengan aktivitasnya sendiri.

Berdasarkan kekurangan-kekurangan yang ada maka perlu ada perbaikan-perbaikan pada Siklus II untuk lebih meningkatkan aktivitas dan hasil belajar siswa. Adapun perbaikan-perbaikannya yaitu: (1) Dalam membangun konsep siswa terhadap materi pembelajaran, guru sebaikanya memberikan apersepsi berupa pertanyaan yang mengaitkan materi dengan kehidupan nyata; (2) Agar tercipta situasi belajar yang kondusif, sebaiknya guru dan siswa membuat kesepakatan berupa aturan dalam kegiatan belajar mengajar yang membuat siswa tidak melakukan aktivitas lain saat guru menjelaskan atau dalam proses pembelajaran; (3) Untuk mengatasi beberapa siswa yang mengalami kesulitan dalam mengoperasikan CD Pembelajaran, sebaiknya guru memberikan bimbingan yang lebih, sebelum proses belajar mengajar dimulai; (4) Saat guru mengajukan pertanyaan sebaiknya guru menunjuk atau menyebutkan nama siswa sehingga siswa tidak lagi menjawab pertanyaan yang diajukan guru secara bersama-sama atau dengan memberikan pengertian kepada siswa apabila guru mengajukan pertanyaan siswa harus mengangkat tangan sebelum menjawab; (5) Sebelum pembelajaran dimulai, sebaiknya guru memberikan penjelasan kepada siswa bahwa siswa harus mengikuti petunjuk dari moderator/guru dalam mengoperasikan CD Pembelajaran sehingga siswa yang tidak bisa ataupun yang sudah bisa mengoperasikan tidak salah dalam menekan ataupun membuka menu yang diperintahkan moderator atau guru; (6) Guru sebaiknya memfasilitasi masing-masing satu Laptop kepada siswa, sehingga siswa dapat lebih fokus dan serius dalam memperhatikan simulasi-simulasi yang ada dalam CD Pembelajaran; (7) Siswa harus diberikan jeda waktu oleh guru dalam memahami setiap simulasi-simulasi yang ada dalam CD Pembelajaran agar siswa lebih paham terhadap materi pembelajaran; (8) Ketika ada beberapa siswa yang sudah berani menanggapi pertanyaan guru, guru harus memberikan penguatan terhadap jawaban siswa sehingga mereka bisa tahu letak kekurangannya; (9) Guru harus membimbing siswa dalam menyimpulkan hasil pembelajaran.

Setelah melihat hasil observasi maupun evaluasi siswa, terlihat hasil yang belum mencapai indikator keberhasilan. Oleh karena itu, penelitian ini harus dilanjutkan di Siklus II untuk memperbaiki Siklus I yang belum berhasil serta untuk meningkatkan aktivitas dan hasil belajar siswa.

Kegiatan yang dilakukan pada Siklus II merupakan perbaikan dari Siklus I dan pelaksanaannya hampir sama dengan Siklus I, tetapi pada Siklus II ada beberapa perbaikan yang dilakukan berdasarkan hasil refleksi Siklus I. Pelaksanaan Siklus II berlangsung dalam dua kali pertemuan. Pertemuan pertama dilakukan pada tanggal 26 Maret 2015 selama 2 × 35 menit dengan membahas materi Faktor-faktor yang Mempengaruhi Gerak pada Benda, pertemuan kedua dilaksanakan pada tanggal 27 Maret 2015 dilaksanakan selama 2 x 35 menit, dengan melanjutkan materi yang belum terselesaikan pada pertemuan pertama selama 1 × 35 menit dan evaluasi Siklus II selama 1 × 35 menit. Soal evaluasi diberikan dalam bentuk tertulis sebanyak 20 soal pilihan ganda. Adapun langkah-langkah pelaksanaan penelitian pada Siklus II adalah sebagai berikut. 
Tahap perencanaan pada Siklus II dalam Penelitian Tindakan Kelas ini sama dengan tahap perencanaan Siklus I.

Tahap selanjutnya adalah pelaksanaan tindakan. Pada dasarnya pelaksanaan pembelajaran pada Siklus II ini sama dengan Siklus I, namun ada sedikit perubahan untuk memperbaiki Siklus I yang kurang berhasil, karena proses pembelajaran pada Siklus II ini dilaksanakan berdasarkan hasil refleksi Siklus I. Adapun langkah-langkah pembelajarannya sebagai berikut.

Guru mengawali kegiatan dengan mengucapkan salam pembuka dan siswa menjawab salam guru dengan penuh semangat dan diikuti dengan aktivitas berdoa yang dipimpin oleh ketua kelas. Selanjutnya guru memberikan motivasi kepada seluruh siswa agar belajar dengan baik dan serius sehingga dapat menambah ilmu dan wawasan mereka, siswa mendengarkan motivasi yang diberikan guru. Setelah siswa mulai termotivasi, guru memberikan apersepsi melalui sebuah pertanyaan yang mengaitkan pembelajaran sebelumnya dengan materi yang akan disampaikan pada hari ini untuk membangun konsep awal siswa terhadap materi pembelajaran dan ada beberapa siswa yang bisa merespon pertanyaan yang diajukan guru, kemudian guru menyampaikan tujuan pembelajaran dan dalam hal ini hampir semua siswa mendengarkan dengan baik tujuan pembelajaran yang disampaikan oleh guru. Setelah itu, guru menjelaskan kepada siswa kegiatan pembelajaran pada hari ini yaitu Computer based instruction Model Simulasi serta mempersiapkan sumber, media, dan alat kelengkapan belajar yang menunjang Computer based instruction dan siswa pun sangat antusias untuk mengikuti proses pembelajaran. Setelah itu, guru bersama siswa membuat kesepakatan bersama, bahwa semua siswa harus mengikuti setiap petunjuk yang ditampilkan melalui LCD Proyektor yang diberikan moderator/guru agar semua siswa bisa mengoperasikan CD Pembelajaran dan semua siswa menyetujui kesepakatan yang diajukan guru.

Guru memfasilitasi masing-masing satu Laptop untuk satu siswa dalam hal ini siswa terlihat begitu senang saat difasilitasi satu Laptop untuk satu orang siswa. Guru menuntun siswa untuk membuka CD Pembelajaran dengan mencontohkan pada slide yang ditampilkan melalui LCD Proyektor dan semua siswa mengikuti petunjuk yang diajukan guru. Setelah semua siswa membuka CD Pembelajaran guru menerapkan Computer based instruction Model Simulasi yang dimulai dengan menampilkan judul program Computer based instruction yang berjudul "Gerak Benda" melalui LCD Proyektor dan siswa memperhatikan dari Laptop yang sudah disedikan. Setelah itu, guru mengajak siswa untuk membuka menu petunjuk dan guru menjelaskan petunjuk penggunaan CD Pembelajaran mulai dari tombol-tombol dan simbol-simbol yang ada dalam CD Pembelajaran melalui LCD Proyektor, dan hampir semua siswa memperhatikan menu petunjuk dengan serius namun masih ada satu dua siswa yang sibuk dengan aktivitasnya sendiri. Langkah selanjutnya, guru menuntun siswa melalui LCD Proyektor untuk membuka menu materi pembelajaran, dalam pertemuan ini guru membahas materi dalam karakter ketiga yaitu Faktor-faktor yang Mempengaruhi Gerak Benda, siswa menekan menu materi berdasarkan petunjuk yang ditampilkan guru melalui LCD. Kemudian guru memberikan waktu kepada siswa untuk memahami setiap simulasi-simulasi yang ada dalam karakter ketiga, dan dalam hal ini siswa terlihat serius untuk memahami simulasi yang ditampilkan dalam CD Pembelajaran.

Langkah selanjutnya, setelah membuka dan memahami materi dalam karakter ketiga siswa diberikan kesempatan untuk bertanya kepada guru apabila ada materi atau simulasi yang belum dipahami, siswa mulai terlihat berani dalam bertanya hal yang belum dipahami, hal ini terjadi karena guru memfasilitasi setiap siswa dengan satu Laptop 
yang membuat siswa lebih termotivasi, fokus, dan lebih serius dalam belajar. Selanjutnya guru memberikan penguatan, dan melakukan tanya jawab dengan siswa terhadap materi yang sudah disampaikan, saat melakukan tanya jawab sebagian besar siswa berani mengangkat tangan dan menjawab pertanyaan guru.

Pada pertemuan kedua ini, guru mereview pertemuan pertama dan melanjutkan materi yang belum terselesaikan melalui penerapan Computer based instruction Model Simulasi.

Selanjutnya tahap observasi. Pelaksanaan obeservasi aktivitas guru dan siswa selama proses pembelajaran berlangusng dinilai oleh dua orang observer. Hasil pengamatan pada pelaksanaan pembelajaran masih dilakukan dengan bantuan observer oleh Ibu A guru kelas III SDN 21 Cakrasia menggunakan lembar observasi guru. Aktivitas guru dalam pembelajaran di kelas dengan menerapkan Computer based instruction Model Simulasi, memperoleh rata-rata skor totalnya 17,5 dengan kategori sangat baik. Kegiatan observasi aktivitas siswa masih diamati oleh NW yang bertindak sebagai Observer II seorang mahasiswi PGSD. Berdasarkan tabel hasil observasi aktivitas siswa di atas, pada Siklus II diperoleh rata-rata skor total 62,5. Hal ini menunjukkan bahwa aktivitas siswa berkategori aktif.

Tahapan selanjutnya adalah evaluasi. Kegiatan evaluasi ini diberikan secara individu dengan memberikan soal pilihan ganda yang berjumlah 20 soal kepada siswa. Evaluasi Siklus I dilakukan pada tanggal 27 Maret 2015. Berdasarkan data hasil belajar, bahwa dari 24 siswa ada 20 orang siswa yang tuntas sedangkan siswa yang belum tuntas ada 4 orang, adapun nilai tertinggi 100 dan nilai terendah 65 Persentase ketuntasan hasil belajar siswa yaitu $83,3 \%$.

Tahapan terakahir yaitu melakukan kegiatan refleksi. Pelaksanaan Siklus II dilaksanakan dua kali pertemuan dengan tindakan yang lebih baik dibandingkan Siklus I. Perbedaan tindakan berupa memfasilitasi satu orang siswa dengan satu Laptop dan dengan tindakan ini siswa terlihat lebih termotivasi, lebih serius, dan lebih fokus dalam memahami setiap simulasi yang ditampilkan dalam CD Pembelajaran dibandingkan dengan Siklus I yang dimana masing-masing meja atau sepasang siswa difasilitasi satu Laptop, selain itu tindakan perbaikan yang dilakukan yaitu guru dan siswa membuat kesepakatan bersama sebelum memulai pembelajaran bahwa semua siswa harus mengikuti petunjuk dalam mengoperasikan CD Pembelajaran dari guru/moderator dan dengan hal ini siswa lebih tertib dalam mengikuti pembelajaran. Adapun dengan perbaikan pelaksanaan tindakan ini jumlah siswa yang tuntas pun meningkat, dari $75 \%$ pada Siklus I menjadi $83,3 \%$ pada Siklus II.

Berdasarkan hasil yang diperoleh secara keseluruhan pada Siklus II ini, penelitian dinyatakan berhasil. Hal ini ditunjukkan dengan adanya peningkatan dari Siklus I ke Siklus II. Oleh karena itu, dilihat dari pencapaian indikator penilaian, pencapaian keberhasilan baik secara kualitatif maupun kuantitatif telah mengalami peningkatan sehingga tidak perlu lagi dilanjutkan ke siklus berikutnya karena indikator keberhasilan peneltian telah dicapai. Siswa yang belum tuntas dikembalikan ke guru kelas untuk diajarkan kembali, dengan pembelajaran yang diterapkan peneliti.

Secara garis besar hasil penelitian pada siklus I menunjukkan bahwa: (1) Jumlah skor aktivitas guru diperoleh skor rata-rata 14.5, skor ini menunjukkan kriteria sangat baik; (2) Jumlah skor aktivitas siswa diperoleh skor rata-rata adalah 47.5 dengan kriteria cukup aktif; (3) Nilai rata-rata hasil belajar IPA siswa adalah 80 , dari jumlah siswa yang mengikuti tes yaitu 23 orang siswa hanya 18 orang siswa yang tuntas dan 6 orang siswa yang tidak tuntas sehingga ketuntasan klasikal yang dicapai yaitu 75\%. Hasil tersebut kurang dari 
target KKM yakni (KKM) $\geq 75$ dengan ketuntasan klasikal sebesar 80\%;

Berdasarkan hasil penelitian tersebut di atas, maka penelitian dilanjutkan ke siklus II.

Pada Siklus II hasil secara garis besar menunjukkan bahwa: (1) Jumlah skor aktivitas guru diperoleh skor rata-rata 17.5 dengan kategori sangat baik; (2) Jumlah skor aktivitas siswa diperoleh skor rata-rataadalah 62.5 dengan kriteria aktif; (3) Nilai rata-rata hasil belajar IPA siswa adalah 80, dari jumlah siswa yang mengikuti tes yaitu 23 orang siswa di mana 20 orang siswa yang tuntas dan hanya 4 orang siswa yang tidak tuntas sehingga ketuntasan klasikal yang dicapai yaitu 83.3\%. Hasil tersebut telah mencapai target KKM yakni $(\mathrm{KKM}) \geq 75$ dengan ketuntasan klasikal sebesar $80 \%$.

Hasil penelitian mengindikasikan peningkatan aktivitas siswa dan juga hasil belajar siswa dari Siklus I ke Siklus II. Pada Siklus I aktivitas belajar siswa termasuk kategori cukup aktif dengan skor total 47.5, aktivitas guru termasuk kategori sangat baik dengan skor total 14.5, dan jumlah siswa yang tuntas 18 orang dengan persentase ketuntasan sebesar $75 \%$. Pada siklus I ini, skor aktivitas siswa belum mencapai kategori aktif dan persentase ketuntasan hasil belajar siswa belum mencapai indikator yang telah ditetapkan yaitu skor aktivitas menunjukkan kategori aktif serta $80 \%$ nilai siswa $\geq 75$. Selanjutnya untuk memperbaiki kekurangankekurangan tersebut, maka dilanjutkan pada siklus selanjutnya atau pada Siklus II.

Proses pembelajaran Siklus II, juga memperlihatkan adanya peningkatan baik dari segi aktivitas siswa dan juga hasil belajar siswa, aktivitas belajar siswa mengalami peningkatan dari total skor 47.5 menjadi 62.5 dan berkategori aktif, begitu halnya dengan skor rata-rata aktivitas guru dari 14.5 menjadi 17.5 dan berkategori sangat baik. Sedangkan hasil belajar siswa dari persentase 75\% menjadi $83.3 \%$. Hal ini menunjukkan penelitian berhasil sesuai dengan indikator ketercapaian. Keberhasilan dari penelitian ini tentunya tidak terlepas dari pembelajaran yang digunakan serta peran guru yang melakukan refleksi dengan baik, sehingga penelitian ini berhasil dengan hasil yang memuaskan di Siklus II. Dari data tersebut menunjukkan indikator ketercapaian penelitian pada siklus II ini telah tercapai sehingga penelitian dihentikan.

Setiap penelitian yang dilakukan tentu memiliki keterbatasannya masing-masing, begitu juga halnya dengan penelitian ini. Penelitian Tindakan Kelas ini memiliki keterbatasan, seperti jenis pembelajaran yang digunakan atau diterapkan dalam penelitian ini tentu tidak dapat dipastikan apakah selalu bisa diterapkan pada kelas lain di sekolah tersebut atau kelas di sekolah lainnya. Tentu saja tidak bisa, dikarenakan setiap kelas di dalam sebuah sekolah tentunya memiliki permasalahan yang berbeda yang tidak mungkin sama dengan kelas sekolah tersebut, begitu juga dengan karakteristik siswa di setiap sekolah tentunya berbeda-beda sehingga dapat dipastikan bahwa setiap guru kelas menghadapi dan mengalami masalah yang berbeda-beda, oleh sebab itu setiap guru tidak dapat menyelesaikan masalah dengan cara atau solusi yang sama juga. Artinya bahwa setiap masalah memiliki penyelesaiannya masing-masing.

Berdasarkan teori yang disampaikan terkait dengan Computer Based Instruction Model Simulasi menurut Lai (2006: 2), menunjukkan bahwa benar pembelajaran ini dapat meningkatkan hasil belajar siswa, karena melalui pembelajaran ini motivasi belajar siswa menjadi lebih tinggi ketika motivasi belajar siswa tinggi kemungkinan besar dapat dipastikan hasil belajarnya juga bisa meningkat. Selain itu, penyajian materi dengan gaya yang berbeda yaitu belajar menggunakan perangkat komputer berupa CD Pembelajaran yang di dalamnya terdapat simulasi-simulasi yang memadukan animasianimasi menarik membuat siswa tidak mudah jenuh dalam belajarnya, sehingga dapat 
disimpulkan bahwa computer based instruction ini dapat meningkatkan hasil belajar siswa.

\section{Kesimpulan}

Berdasarkan hasil penelitian, disimpulkan bahwa: (1) Penerapan Computer Based Instruction Model Simulasi dalam pembelajaran IPA SDN Cakrasia bisa meningkatkan aktivitas guru dan aktivitas belajar siswa kelas. Peningkatan aktivitas guru dapat dilihat dari data pada Siklus I memperoleh skor sebesar 14.5 yang berkategori sangat baik meningkat menjadi 17.5 dan masih berkategori sangat baik. Peningkatan juga terjadi pada aktivitas siswa, pada Siklus I memperoleh skor sebesar 47.5 yang berkategori cukup aktif meningkat menjadi 62.5 yang berkategori aktif; (2) Penerapan Computer Based Instruction Model Simulasi pada pelajaran IPA SDN Cakrasia mampu mempertinggin hasil belajar siswa di kelas. Peningkatan hasil belajar dapat dilihat dari ketuntasan klasikal yang pada Siklus I mendapat persentase sebesar $75 \%$ meningkat menjadi $83.3 \%$ pada Siklus II.

\section{Daftar Pustaka}

Rusman. (2012). Model-model Pembelajaran Mengembangkan Profesionalisme Guru. Jakarta: Grafindo Persada.

Rusman. (2013). Belajar dan Pembelajaran Berbasis Komputer Mengembangkan Profesionalisme Abad 21. Bandung: Alfabeta.

Heinich, R., Molenda, M., Russell, J.D., \& Smaldino, S.E. (2002). Instructional Media and Technologies for Learning ( $\left.7^{\text {th }}\right)$. New Jersey: The Lehigh Press.

Susilana, R., \& Riyana, C. (2009). Media Pembelajaran: Hakikat, Pengembangan, Pemanfaatan, dan Penilaian. Bandung: CV Wacana Prima.

Sugar, W., \& Brown, A. (2008). Antecedents of Computer Based Instruction and Its Current Relationship to Our Discipline:
An Examination of Last Fifty Years of DAVI/AECT Convention Presentations.TechTrends, 52(2), 59-69.

Darmawan, Deni. (2012). Inovasi Pendidikan. Bandung: PT Remaja Rosdakarya.

Akcay, H., et al. (2006). Effects of Computer Based Learning on Students' Attitudes and Achievements Towards Analytical Chemistry. Journal of Educational Technology. 5(1), 44-48.

Kozma, R. B. (1994). The Influence of Media on Learning: The Debate Continues A New Look at the Question. SLMQ. 22(4).

Kunandar. (2010). Langkah Mudah Penelitian Tindakan Kelas sebagai Pengembangan Profesi Guru. Jakarta: Grafindo Persada.

Mayer, R. E., \& Moreno, R. (2002). Aids to Computer-Based Multimedia Learning. Learning and Instruction. 12, 107-119.

Tabor, S. W., \& Minch, R. P. (2013). Student Adoption \& Development of Digital Learning Media: Action Research and Recommended Practices. Journal of Information Technology Education: Research. 12, 203-223.

Pandolfini, V. (2013). Innovation and education systems: teachers experiencing Interactive Whiteboards. Journal of Scientific and Research Publications. 3(10), 1-8.

Abdi, A. (2014). The Effect of Inquiry-based Learning Method on Students Academic Achievement in Science Course. Universal Journal of Educational Research. 2(1), 37-41.

Slamet, A., Sudargotapilouw, F., \& Rohman, I. (2014). Critical Thinking Ability Analysis Beginning Teacher Candidates Of Biology in the Animal Physiology Material At Biology Education Program Fkip Sriwijaya University. Journal of Scientific and Research (IJSR). 3(7), 10381042.

Institutes, A. (n.d.). Learning with Computer Games and Simulations.

Lai, C.-C. (2006). The Advantages and Disadvantages of Computer Technology 
in Second Language Acquisition. National Journal for Publishing and Mentoring Doctoral Student Research. 3(1), 1-6.

Winter, F. I., Greene, J. A., \& Costich, C. M. (2008). Self-Regulation of Learning within Computer-based Learning Environments: A Critical Analysis. Educ Psychol Rev. 20, 429-444.

Kazu, I. Y. (2005). The Effects of Mastery Learning Model on the Success of the Students Who Attended " Usage of Basic Information Technologies " Course. Educational Technology and Society. 8(4), 233-243.

Ahmed, A. K. (2013). Teacher-Centered Versus Learner -Centered Teaching Style. The Journal of Global Business Management. 9(1), 22-34.

Arikunto, Suharsimi. (2010). Prosedur Penelitian Suatu Pendekatan Praktik. Jakarta: Rineka Cipta.

Kemendikbud, \& Pusat Data dan Statistik Pendidikan dan Kebudayaan. (2017). Ikhtisar Data Pendidikan Tahun 2016/2017.

Turkkahraman, Mimar. (2012). The Role of Education in The Societal Development. Journal of Educational and Instructional Studies in The World. 2(4), 38-41.

Maher, Angela. (2004). Learning Outcomes in Higher Eduction: Implications for Curriculum Design and Student Learning. Journal of Hospitality, Leisure, Sport and Tourism Education. 3(2), 46-54.

Wang, S.T., \& Chen, C.C. (2015). Path Analysis on the Factors Influencing Learning Outcome for Hospitality Interns-From the Flow Theory Perspective. Journal of Education and Learning. 4(3), 25-44.

Potter, M.K., \& Kustra, E. (2012) A Primer on Learning Outcomes and the SOLO Taxonomy. Center for Teaching and Learning, University of Windsor. 